\begin{tabular}{l}
\hline Jurnal Scripta Teologi dan Pelayanan Kontkestual \\
ISSN 2086-5368 (Print) \\
ISSN \\
Http://ejournal.stte.ac.id \\
Vol.1, No.2, pp. 1-20, 2016
\end{tabular}

\title{
Ekspository Preaching: Jawaban Terhadap Kebutuhan Sistem Berkhotbah Masa Kini
}

Aris Elisa Tembay, M.Th

STT Ebenhaezer Tanjung Enim, aristembay@gmail.com

\begin{tabular}{l}
\hline INFO ARTIKEL \\
\hline Sejarah Artikel: \\
Diterima: 05 Nov 2016 \\
Direvisi: 11 Nov 2016 \\
Disetujui: 17 Nov 2016 \\
Dipublikasi: 28Nov \\
2016
\end{tabular}

Kata Kunci:

keyword one, keyword two, keyword three.

\section{Keywords:}

keyword one, keyword two, keyword three.

\section{ABSTRAK}

Dalam ilmu Homeletika, dikenal ada tiga jenis khotbah; yakni khotbah Topikal, Tekstual, dan Ekspositori. Dibandingkan dengan dua jenis khotbah yang lain, ekspositori memiliki ciri-ciri dan kelebihan tersendiri, oleh karena pengkhotbah sangat terikat dengan teks yang dikhotbahkan dan teks tersebut harus merupakan teks yang lengkap seperti satu perikop. Sesuai dengan namanya "Ekspositori" adalah memberitakan atau mengekspos kebenaran Firman Allah dalam satu rangkaian yang terdiri dari tema, pokok-pokok besar dan kecil yang kesemuannya bersumber dari teks. Sehingga menolong pengkhotbah untuk jauh dari penafsiran alegoris, karena seluruh khotbah terdiri dari suatu penjelasan terperinci tentang satu bagian tertentu dari Alkitab dan nats Alkitab itu terjalin dalam seluruh uraian. Khotbah ekspositori menolong jemaat atau pendengar untuk mudah mengerti maksud dan tujuan Firman Tuhan, karena yang diberitakan bukan ide pengkhotbah tetapi murni penguraian dari teks yang dibacakan. Di samping itu sistematika ekspositori yang menguraikan pokok-pokok besar dan kecil bersumber dari tema yang berasal dari teks, memudahkan pendengar untuk mengerti bahkan mengingat Firman Tuhan yang diberitakan. Oleh sebab itu khotbah ekspositori adalah jawaban bagi tantangan pemberitaan Firman Tuhan masa kini.

\section{ABSTRACT}

In Homiletics, there are three types of preaching known; namely Topical, Textual, and Expository sermons. Compared with the other two types of preaching, the expository has its own characteristics and advantages, because the preacher is very bound to the text being preached and the text must be a complete text like a passage. In accordance with its name "Expository" is to preach or expose the truth of God's Word in a series consisting of themes, big and small points whose findings are sourced from the text. So it helps the preacher to be 
far from allegorical interpretation, because the entire sermon consists of a detailed explanation of one particular part of the Bible and the scriptures are intertwined in the entire description. Expository preaching helps the congregation or listener to easily understand the purpose and purpose of God's Word, because what is preached is not the preacher's idea but purely a decomposition of the text read. In addition, expository systematics that outlines the major and minor points of origin comes from themes originating from the text, making it easy for listeners to understand and even remember the Word of God preached. Therefore expository preaching is the answer to the challenges of preaching God's Word today.

\section{Pendahuluan}

Dalam tulisan ini akan penulis menguraikan tentang hakikat khotbah ekspositori yang pembahasannya mencakup defenisi khotbah ekspositori, latar belakang timbulnya khotbah ekspositori, ciri-ciri khotbah ekspositori, keunggulan dan unsurunsur khotbah ekspositori, sehingga khotbah ekspositori dapat menjadi jawaban atas tantangan pemberitaan Firman Tuhan masa kini.

\section{Metode Penelitian}

Dalam penelitian ini, menggunakan paradigma penelitian kualitatif, pendekatan sistematis dan subjektif dalam menjelaskan pengalaman hidup berdasarkan kenyataan lapangan. Penelitian ini berorientasi kepada upaya untuk memahami fenomena secara menyeluruh. ${ }^{1}$ Metode yang digunakan adalah metode deskriptif teologis, penelitian yang memberikan gambaran atau penegasan suatu konsep atau gejala, juga menjawab pertanyaan-pertanyaan sehubungan dengan status subjek penelitian pada saat ini. ${ }^{2}$ Menurut Koentjaraningrat penelitian deskriptif adalah metode yang mengambarkan secara tepat sifat-sifat suatu individu, keadaan, gejala atau kelompok tertentu, atau untuk menentukan frekuensi adanya hubungan tertentu adanya suatu gejala dan gejala lain dalam masyarakat. ${ }^{3}$

\section{Hasil Dan Pembahasan}

\section{Defenisi Khotbah Ekspositori}

Khotbah berasal dari kata omelein, omilew (homelein, homileo) dan kata bendanya omilia (homilia). Homelein berarti berada bersama-sama, bergaul atau persekutuan, kontak dengan orang lain, berkawan, bercakap-cakap, pembicaraan. Kemudian istilah ini semakin berkembang dan makin rinci artinya yakni bercakap-cakap atau berbicara dengan seseorang atau dengan beberapa orang. ${ }^{4}$

Khotbah merupakan keterampilan dalam mengkomunikasikan konsep atau gagasan Alkitabiah yang dapat diambil melalui penafsiran yang benar dari ayat-ayat

\footnotetext{
${ }^{1}$ Iskandar, Metodologi Penelitian Kualitatif, (Jakarta: Gaung Persada, 2009), 35

${ }^{2}$ Sumanto, Metodologi Penenlitian Sosial dan Pendidikan, (Yogyakarta: Andi Offset), 6

${ }^{3}$ Koentjaraningrat, Metode-metode Penelitian Masyarakat, (Jakarta: Gramedia, 1981), 42

${ }^{4}$ E. P. Gintings, Khotbah dan Pengkhotbah, (Jakarta: BPK Gunung Mulia, 2000), hlm. 1
} 
Alkitab dan diterapkan melalui kuasa Roh Kudus pada kehidupan pengkhotbah dan juga pendengar khotbah. 5

Melihat pernyataan di atas maka khotbah adalah keahlian dalam memberitakan kabar kesukaan yakni suara hati Allah yang telah ada di dalam Alkitab kepada manusia melalui para hambaNya yang telah dipanggil agar manusia dapat memahami kebenaran dan keselamatan yang telah dinyatakan di dalam Yesus Kristus yang pada akhirnya mengalami kelahiran baru.

Para ahli lainnya berpendapat bahwa khotbah adalah salah satu unsur terpenting dari seseorang hamba Tuhan, karena berkhotbah berarti menyampaikan Firman Allah kepada jemaat. ${ }^{6}$ Dengan demikian diharapkan jemaat yang mendengar firman Allah mengalami perubahan hidup oleh Firman Allah yang telah disampaikan oleh pengkhotbah.

Williams Evans memberikan definisi singkat tentang khotbah yakni, memberitakan kabar kesukaan, dilakukan olah seorang manusia dan ditujukan kepada sesamanya manusia.7 Searah dengan itu P. H. Pouw mengatakan bahwa khotbah merupakan satu pembicaraan yang menerangkan jalan keselamatan manusia melalui Yesus Kristus, yang dilakukan oleh mulut manusia supaya menjadi kesaksian bagi manusia yang lain. ${ }^{8}$

Dengan memperhatikan beberapa pernyataan di atas maka dapat disimpulkan bahwa khotbah adalah menyampaikan atau memberitakan firman Allah kepada orang lain yang dilakukan oleh seseorang dalam membawa orang lain untuk mengalami pembaharuan hidup serta memperoleh kebenaran dan keselamatan di dalam dan melalui Yesus Kritus.

Dalam kamus teologi ekspositori diartikan menjelaskan, menguraikan. ${ }^{9}$. Sedangkan dalam Cassell's New Compact Latin Dictionary dikatakan: "Expositio is Pitting Out, Kence Statement exposition naration". ${ }^{10}$

Ekspositori tidak dapat dipisahkan dari dua istilah yakni eksegese dan eksposisi. Kata eksegese berasal dari kata Yunani "exńge, omai" dalam bahasa inggris "exegesis" yang berarti: "to lead out, signifies, to make known, rehearse, declare"."11 Istilah ini secara dasar memberikan suatu pengertian memimpin keluar atau mengantar, serta membuat atau menjadikan pendengar menjadi tahu dan mengerti. Eksegese adalah menerangkan dan menjelaskan arti dari suatu bagian dalam Alkitab. ${ }^{12}$ Searah dengan hal ini Jerry Vines mengatakan bahwa eksegese bisa dirumuskan sebagai prosedur yang diikuti seseorang sewaktu mencari maksud Roh Kudus dalam suatu bacaan Alkitab. ${ }^{13}$ Jadi yang dimaksud dengan eksegese adalah mempelajari atau menganalisa dengan teliti dan sistematis untuk menemukan dan mengangkat keluar dari asli yang dimaksudkan dalam teks Alkitab serta membawa pendengar menjadi mengerti dan memahami arti teks.

\footnotetext{
${ }^{5}$ Hendra Rey, Homelitika "Perlengkapan"

${ }^{6}$ Yap Un Han, Problematika Hamba Tuhan, (Manado: Yayasan Daud Family, 1998), hlm. 67

${ }^{7}$ Williams Evans, Cara Mempersiapkan Khotbah, (Jakarta: BPK Gunung Mulia, 1986), hlm. 9

${ }^{8}$ H. P. Pouw, Homeletik, (Bandung: Kalam Hidup, tt), hlm. 9

${ }^{9}$ Henk ten Napel, Kamus Teologi Inggris-Indonesia, (Jakarta: BPK Gunung Mulia, 2000), hlm. 133

${ }^{10}$ D. P. Simpson, Compact Latin Dictionary, (New York: Dell Publishing co-inc, 1971), p. 86

11 W. E. Vine, Merril F. Unger., William White, Jr., Vine's Expository Dictionary of Biblical Word, (Nashiville: Thomas

${ }^{12}$ M. E. Manton, Kamus Istilah Teologi, (Malang: Gandum Mas, 1995), hlm. 62

${ }^{13}$ Jerry Vines, Homelitik (Kuasa dalam berkhotbah), (Malang: Gandum Mas, 2002), hlm. 37
} Nelson Publisher, 1985), p. 152 
Eksposisi dalam bahasa inggris "exposition" artinya: penjelasan yang terperinci, karangan yang menjelaskan, proses atau gagasan. ${ }^{14}$ Sedangkan kata eksposisi dalam kamus umum bahasa Indonesia diartikan: petunjuk penerangan, penjelasan. ${ }^{15}$ Eksposisi dalam hubungannya dengan penafsiran Alkitab lebih mengarah pada aplikasi. ${ }^{16}$ Dengan kata lain eksposisi merupakan penerapan dari hasil eksegese untuk pembaca masa kini atau pendengar.

Dari kedua istilah di atas jelas bahwa hubungan antara eksegese dengan eksposisi sangat erat, karena eksegese merupakan dasar dari eksposisi sedangkan eksposisi memperlihatkan, menyatakan, mengaplikasikan hasil dari eksegese.

Bila kedua istilah khotbah dengan ekspositori digabungkan maka pengertian khotbah ekspositori merupakan sebuah metode dalam ilmu homiletika. James Braga memberikan pengertian khotbah ekspositori dalam bukunya yang berjudul Cara Mempersiapkan Khotbah, sebagai berikut:

Khotbah ekspositori adalah suatu khotbah dimana suatu bagian Alkitab yang pendek atau panjang diartikan dalam hubungan dengan satu tema atau pokok. Bagian terbesar materi khotbah diambil langsung dari nas Alkitab tersebut dan kerangkanya terdiri sendiri dari serangkaian ide yang diuraikan secara bertahap dan berpangkal pada satu ide utama. ${ }^{17}$

Dalam buku "Cara Berkhotbah Yang Baik" Haddon W. Robinson memberikan definisi dari khotbah ekspositori yakni:

"Khotbah ekspositori merupakan komunikasi atas suatu konsep Alkitab yang diperoleh dan disampaikan melalui suatu studi historis, gramatikal, dan kesusatraan atas suatu nukilan Alkitab sesuai dengan konteks, yang pertama-tama diterapkan oleh Roh Kudus kepada pribadi dan pengalaman pengkhotbahnya, baru kepada pendengarnya." 18

Sedangkan P. H. Pouw memberikan pengertian khotbah ekspositori yakni:

"Khotbah yang berisi penafsiran, penguraian dan pelajaran rohani. Untuk berkhotbah jenis ini biasanya dipakai sebagian dari pada satu pasal seluruh pasal atau lebih dari pada satu pasal sesuai dengan pimpinan Roh kepada pengkhotbah, ayat itu dibacakan kemudian ditafsirkan satu persatu."19

Searah dengan itu Paul Borden memberikan komentar tentang khotbah ekspositori. Menurut Borden khotbah ekspositori suatu khotbah yang mengandung suatu ide utama yang diperoleh dengan penafsiran yang tepat atas suatu bagian atau beberapa bagian dari Alkitab. Setiap bagian Alkitab mempunyai satu ide utama yang didukung oleh ide-ide sekunder. ${ }^{20}$

D. W. Lee mengutip perkataan Jerry Vines yang mengatakan: "Khotbah ekspositori adalah khotbah yang menafsirkan suatu bagian dari Alkitab, lalu disusun dan dikembangkan dengan berpusatkan pada satu tema, kemudian diterapkan ke dalam situasi pendengar." 21

Khotbah ekspositori tidak harus dibuat hanya berdasarkan satu bagian Alkitab, namun jenis khotbah yang demikian menuntut proses penafsiran yang teliti atas

\footnotetext{
${ }^{14}$ John M. Echols, Kamus Inggris-Indonesia, (Jakarta: PT Gramedia Pustaka Utama, 2000), hlm. 225

${ }^{15}$ W.J.S. Poerwadarminta, Kamus Umum Bahasa Indonesia, (Jakarta: Balai Pustaka, 1991), hlm. 268

${ }^{16}$ Hasan Susanto, Hermeneutik, (Prinsip dan Metode Penafsiran Alkitab), (Malang: SAAT, 1995), hlm. 3-4

${ }^{17}$ James Braga, Cara Mempersiapkan Khotbah, (Malang: Penerbit Gandum Mas, 1968), hlm. 45

${ }^{18}$ Haddon W. Robinson, Cara Berkhotbah Yang Baik, (Yoyakarta: Yayasan Andi, 2002), hlm. 14

${ }^{19}$ P. H. Pouw, Homelitik... hlm. 104

${ }^{20}$ Michael A. Dubit, Hand Book of Contemporary Preaching, (Nsah Ville, Tennesse: Broodman Prees, 1992), p. 63

${ }^{21}$ D. W. Lee, Khotbah Ekspositori yang membangunkan Pendengar, (Bandung: Lembaga Literatur Baptis, 2000), hlm. 119
} 
bagian Alkitab. Selain itu garis besar suatu khotbah harus konsisten dengan garis besar bagian atau bagian-bagian yang lain dari Alkitab yang dikhotbahkan.

Dari beberapa definisi di atas tidak sama dengan para pakar homelitik yang lain yang melihat khotbah ekspositori sebagai khotbah yang dibuat berdasarkan bagian Alkitab yang lebih panjang, katakanlah lebih dari 3 ayat atau dengan kata yang lain khotbah yang butir-butir utama dan butir-butir sekundernya diambil langsung dari Alkitab 22

Dari uraian di atas maka dapat disimpulkan bahwa khotbah ekspositori ialah suatu metode khotbah dalam mengkomunikasikan Firman Allah kepada jemaat melalui seorang pengkhotbah yang telah hidup dan dikuasai oleh Roh Kudus serta mengalami pembaharuan hidup dengan memakai prinsip-prinsip hermeneutik dalam menafsirkan teks Alkitab, dan firman yang disampaikan membawa orang yang mendengar mengalami hidup baru di dalam dan melalui Yesus Kristus.

\section{Latar Belakang Keberadaan Khotbah Ekspositori}

Keberadaan khotbah ekspositori sudah dimulai sejak masa PL oleh para nabi dalam menyampaikan firman Allah kepada umatNya. Perkembang keberadaan khotbah ekspositori tidak hanya sampai di sini, tetapi terus berkembang dan dilanjutkan penggunaannya oleh para rasul dalam PB dalam memberitakan Injil kepada umat Tuhan. Selain itu para theolog dan bapa-bapa gereja juga telah menggunakannya yang sampai sekarang para tokoh-tokoh homelitik menjadikannya salah satu jenis khotbah dalam ilmu homelitik.

\section{Masa Perjanjian Lama}

Perkembangan keberadaan khotbah ekspositori sudah dimulai sejak para nabi dalam Perjanjian Lama. Ini tampak ketika para nabi langsung menerima, mengalami dan menyampaikan firman Allah kepada manusia. Para nabi dalam Perjanjian Lama menyampaikan firman Allah melalui khotbah ekspositori dalam dua bentuk yang mendasar yaitu khotbah yang bersifat penatalayanan dan khotbah yang bersifat menjelaskan. ${ }^{23}$

Para nabi pada waktu itu menyampaikan sesuatu kepada umat Tuhan bukan atas pandangan sendiri, tetapi mengabarkan dan menyampaikan Firman Allah seperti yang sering tertulis “demikianlah Firman Tuhan”. Dalam memberitakan Firman Allah, para nabi memakai dua pola khotbah yakni memberitakan hukum atas dosa dan memberitakan kabar keselamatan. ${ }^{24}$ Inilah yang dipakai oleh para Nabi untuk menyampaikan Firman dan kehendak Allah kepada umatNya.

Dalam Nehemia pasal 8 dapat dilihat bagaimana imam Ezra memakai khotbah ekspositori ketika ia menyampaikan pesan Allah kepada bangsa Israel. "bagian-bagian dari kitab itu, yakni taurat Tuhan, dibacakan dengan jelas dengan diberi keteranganketerangan, sehingga pembacaan dimengerti, "semua orang itu menangis ketika mendengar kalimat-kalimat Taurat itu". ${ }^{25}$ D. W. Lee memahami khotbah Ezra sebagai khotbah yang menggunakan pola khotbah ekspositori, oleh karena dalam khotbah Ezra dapat dilihat dia memilih teks, menafsirkan teks, menerapkan teks itu ke dalam

\footnotetext{
${ }^{22}$ Hasan Susanto, Homelitik (Prinsip dan Metode Berkhotbah), (Jakarta: BPK Gunung Mulia, 2004), hlm. 210

${ }^{23}$ Mac Athur Jr. Jhon F, Rediscovering Exspository Preaching, (Dallas: word, 1992), p. 38-39

${ }^{24}$ E. P. Gintings, Khotbah dan Pengkhotbah... hlm. 7

${ }^{25}$ Nehemia 8: 9-10
} 
kehidupan rakyat, dan pada akhirnya rakyat Israel mengambil keputusan untuk memperbaharui kehidupan mereka karena sadar akan dosa. ${ }^{26}$

Dengan memperhatikan pernyataan di atas secara nyata Ezra menjadi salah satu tokoh dan contoh dalam Perjanjian Lama yang memakai metode khotbah ekspositori. Jadi khotbah ekspositori sudah ada sejak Perjanjian Lama hanya saja belum dipahami dan dikembangkan dalam pengertian ekspositori oleh para pengkhotbahnya.

\section{Masa Perjanjian Baru}

Pada jaman Perjanjian Baru khotbah ekspositori disampaikan oleh Tuhan Yesus sendiri yang adalah Sang Firman itu, ${ }^{27}$ kemudian para rasul melanjutkannya. Di dalam Lukas pasal 4: 16-21 dapat dilihat bagaimana semangat khotbah ekspositori yang dipakai oleh Tuhan Yesus ketika la berkhotbah di rumah ibadat Nazaret

"la datang ke Nazerat tempat la dibesarkan, dan menurut kebiasaannya pada hari sabat ia masuk ke rumah ibadat, lalu ia berdiri hendak membaca Alkitab. kepadaNya diberikan kitab nabi Yesaya dan setelah dibukanya, la menemukan nas dimana ada tertulis: 'Roh Tuhan ada pada-Ku, oleh sebab la telah mengurapi Aku, untuk menyampaikan kabar baik kepada orang-orang miskin; dan la telah mengutus Aku untuk memberitakan pembebasan kepada orang-orang tawanan dan penglihatan bagi orang-orang buta, untuk membebaskan orang-orang tertindas, untuk memberitakan tahun rahmat Tuhan telah datang'. Kemudian la menutup kitab itu memberikannya kembali kepada pejabat, lalu duduk; dan mata semua orang di dalam rumah ibadat itu tertuju kepadaNya lalu la mulai mengajar mereka, kataNya: 'Pada hari ini genaplah nas ini sewaktu kamu mendengarnya."28

Tuhan Yesus membaca Alkitab dan menyampaikan firman dengan dasar Alkitab yang la baca. Tuhan Yesus memakai prinsip penafsiran Alkitab yang baik dan benar yakni kembali kepada Alkitab sebagaimana salah satu prinsip penafsiran yang disampaikan oleh Calvin bahwa Alkitab menafsirkan Alkitab. ${ }^{29}$ Ciri dari khotbah ekspositori adalah pemakaian hermeneutika yang baik dan benar dalam menafsirkan Alkitab. Selain itu hal yang perlu diperhatikan dalam khotbah Tuhan Yesus di rumah ibadat Nazaret adalah penggenapan firman itu terjadi melalui Dia sendiri. Prinsip khotbah ekspositori yang ditekankan oleh para pengkhotbah ekspositori yakni unsur Kristologi. ${ }^{30}$ Inilah prinsip khotbah ekspositori yang dapat dilihat dalam khotbah Tuhan Yesus di rumah ibadat Nazaret. Tuhan Yesus menyampaikan firman Allah dengan berpatokan pada kebenaran dari seluruh Alkitab. Tuhan Yesus menunjukkan identitas dan kualitas sebagai seorang pengkhotbah yang baik di samping sebagai guru agung. ${ }^{31}$ Dengan demikian Tuhan Yesus pada dasarnya telah menggunakan bentuk-bentuk dari khotbah ekspositori, hanya saja pada waktu itu belum dipahami sebagai jenis khotbah ekspositori.

Para rasul juga menggunakan khotbah ekspositori dalam memberitakan Firman Allah kepada jemaat Tuhan. Hal ini dapat dilihat dalam pribadi dan pelayanan rasul Petrus ketika ia berkhotbah dengan kuasa Roh Kudus sehingga banyak orang bertobat dan menerima Yesus sebagai juru selamatnya. ${ }^{22}$

\footnotetext{
${ }^{26}$ D. W. Lee, Khotbah Ekspositori Yang Membangunkan... hlm. 126-127

${ }^{27}$ Yohanes 1: 14

${ }^{28}$ Lukas 4: 16-21

${ }^{29}$ Hasan Susanto, Hermeneutik, (Malang: Seminari Alkitab Asia Tenggara, 1995), hlm. 72

${ }^{30}$ D. W. Lee, Khotbah Ekspositori Yang Membangunkan... hlm. 128

${ }^{31}$ Band. Mat. 9: 35; Mark. 1:14 dan Mat. 7: 29; 10: 35-37; Mark. 12: 37; Luk. 2: 40, 52 dan 24: 27, 44

${ }^{32}$ Kisah Para Rasul 2: 41
} 
Dalam Perjanjian Baru seorang pengkhotbah ekspositori yang terkenal dan besar adalah Rasul Paulus. Dalam Kisah Para Rasul 17: 1-4, Paulus menyampaikan firman Tuhan kepada jemaat di Tesalonika. la membicarakan bagian-bagian kitab suci dan menerangkannya. Paulus bukan hanya menyampaikan teori dari apa yang telah dibacakan, tetapi menerangkan dan menerapkannya dalam kehidupan jemaat Tesalonika.

Paulus memilih teks secara konkrit dan menafsirkan serta menerapkannya, kemudian mengambil kesimpulan bahwa Kristus adalah juru selamat. Hal ini yang mengandung prinsip Kristologis sebagaimana yang ditekankan oleh para pengkhotbah ekspositori.33 Paulus dalam surat-suratnya juga selalu mengkhotbahkan tentang kehidupan Tuhan Yesus, 34 mengingatkan para pendengar kepada karya Kristus, ${ }^{35}$ dan dalam kehidupan para rasul lainnya seperti: Stephanus ${ }^{36}$ dan Yakobus. ${ }^{37}$ Jadi para rasul memberikan suatu era baru dalam metode khotbah tentang khotbah ekspositori mengenai penggenapan janji-janji Allah kepada manusia di dalam dan melalui Yesus Kristus.

\section{Masa Reformasi}

Pada masa reformasi khotbah para reformator selalu membela keabsahan Alkitab yang adalah firman Allah dan sekaligus berusaha keras menentang tradisi serta sakramen gereja Katolik. Kelompok yang menekankan khotbah ekspositori adalah kebanyakan pengkhotbah reformator. Marthin Luther sebagai salah seorang tokoh reformator sangat menghargai Firman Allah dan Roh Kudus yang mampu memberikan kebenaran dan keselamatan di dalam Yesus Kristus. ${ }^{38}$ Tokoh yang lainnya adalah Zwingli, seorang pengkhotbah pada masa reformasi yang sangat memperhatikan tata bahasa dan eksegese suatu teks firman Tuhan. John Calvin dalam kehidupan pelayanannya sangat menunjukkan betapa pentingnya mempelajari, menginterprestasi dan mengkhotbahkan firman Allah. Calvin merupakan seorang pengkhotbah yang loyal pada Alkitab, seorang ekspositori yang baik dan seorang penginjil yang terkenal pada masanya bahkan sampai sekarang. 39

\section{Masa Pasca Reformasi}

Setelah periode reformasi, golongan puritan ${ }^{40}$ menghadirkan tokoh-tokoh pengkhotbah ekspositori yang memberikan dampak positif bagi pertumbuhan gereja di dunia. Perkembangan selanjutnya menunjukkan bahwa Tuhan memakai para pengkhotbah ekspositori untuk mengembangkan jemaatnya.

Dari sejumlah tokoh yang terkenal pada masa pasca reformasi penulis akan menyebutkan sebagian tokoh yang mewakili para tokoh lainnya. Seorang bernama Alexander Mclaren pembuka secara modern khotbah ekspositori. F. B. Muyer atau Campball Morgan juga terkenal sebagai orang yang memperkenalkan khotbah ekspositori secara umum. Tetapi memberikan semangat dan teladan yang konkrit pada khotbah ekspositori adalah Martin Lloyd Jones (1896-1981) meyakini bahwa khotbah

\footnotetext{
${ }^{33}$ D. W. Lee, Khotbah Ekspositori Yang Membangunkan... hlm. 129

${ }^{34}$ I Kor. 1: 23; $2: 2$ dan II Kor. 4: 5

${ }^{35}$ Rom. 1: 18; I Kor. 2: 10; Ef. 3: 5

${ }^{36}$ Kis. 7: 2-53

${ }^{37}$ Kis. $15: 14-21$

${ }^{38}$ D. W. Lee, Khotbah Ekspositori Yang Membangun...hlm. 130

${ }^{39}$ Dantje K. T. Pandwal, Khotbah Ekspositori dan Peranannya...hlm. 25-26.

${ }^{40}$ Golongan puritan adalah golongan yang memegang teguh peraturan
} 
firman Allah adalah kekuatan dalam kekuasaan, kemuliaan, ketelitian dan kemurnian serta sangat relevan. ${ }^{41}$

Akhir-akhir ini orang yang berkarya tentang khotbah ekspositori dan juga memberikan pengaruh yang baik adalah John Stott. Melalui sejarah orang dapat menemukan akar dan jenis khotbah secara khusus jenis khotbah ekspositori yang diturunkan dari generasi ke generasi. Khotbah ekspositori menjadi satu aliran yang terkenal sampai sekarang.

\section{Ciri-Ciri Khotbah Ekspositori}

Pada bagian awal telah dijelaskan pengertian khotbah ekspositori. Jenis khotbah ekspositori merupakan suatu metode dalam mengkomunikasikan Injil yakni firman Allah yang harus diterapkan dalam kehidupan dan pribadi pengkhotbah serta pendengar. Dalam memahami bahwa seorang pengkhotbah memakai jenis khotbah ekspositori, maka perlu diperhatikan ciri-ciri khotbah ekspositori. ${ }^{42}$

\section{Didasarkan Pada Seluruh Kebenaran Alkitab}

Khotbah Ekspositori dikatakan suatu khotbah yang Alkitabiah adalah karena sumber khotbah selalu didasarkan dari Tuhan melalui Alkitab. Firman yang dikomunikasikan benar-benar berasal dari Tuhan melalui hasil perenungan Alkitab. Seorang pengkhotbah tidak dapat mengandalkan kekuatannya sendiri misalnya pengetahuan dan keterampilan lainnya. Tetapi seorang pengkhotbah ekspositori harus menunjukkan suatu karya rohani yang dialami sendiri serta nampak dalam kehidupannya. Seorang pengkhotbah dapat mengkomunikasikan firman Allah dengan Alkitabiah apabila ia membina spiritualitas yang baik dengan Tuhan. Prinsip ini sangat penting karena Alkitab adalah standart yang mutlak bagi pengkhotbah. Banyak para pengkhotbah mengalami kegagalan karena bergantung pada pengalaman dan pengetahuan pribadi dan tidak mengandalkan kuasa Tuhan dan peranan Roh Kudus.

Rasul Paulus memberi teladan yang baik mengenai sikap seorang pengkhotbah, yang berbunyi demikian:

“Tetapi aku melatih tubuhku dan menguasainya seluruhnya supaya sesudah memberitakan Injil kepada orang lain, jangan aku sendiri ditolak, jangan seorangpun menganggap engkau rendah karena engkau muda. Jadilah teladan bagi orang-orang percaya dalam perkataanm, dalam tingkah lakumu, dalam kasihmu, dan dalam kesetiaanmu, dan dalam kesucianmu."43

Seorang pengkhotbah harus hidup di dalam firman Tuhan terlebih dahulu, sehingga khotbah yang disampaikan tidak dimanipulasi oleh daya retorik semata, melainkan tertuju kepada karya keselamatan di dalam Tuhan Yesus Kristus. Oleh karena itu hal-hal seperti kepribadian, panggilan dan kerohanian pengkhotbah justru lebih menentukan keberhasilan sebuah khotbah dari pada teknik membuat dan menyampaikan khotbah.

Seorang pengkhotbah sangat perlu memperhatikan kepribadian, panggilan dan kerohaniannya, karena khotbah sesungguhnya bukan sekedar sebuah karya yang dibuat berdasarkan tafsiran. Tetapi ada unsur lain yang melebihi teknik penafsiran yakni kasih terhadap Tuhan dan sesama. ${ }^{44}$ Jadi dalam mempersiapkan sebuah khotbah,

\footnotetext{
${ }^{41}$ D. W. Lee, Khotbah Ekspositori Yang Membangun...hlm. 130

${ }^{42}$ Poin-poin ini diambil dalam buku J. Gulleson, yang berjudul "Bagaimana Berkhotbah (jenis Ekspositori)", hlm. 9-17

${ }^{43} 1$ Korintus 9:27; 1 Timotius 4:12.

${ }^{44}$ Hasan Susanto, Homiletik...hlm. 52
} 
setiap perasaan pengaruh psikologis dari seorang pengkhotbah harus dikuduskan terlebih dahulu oleh kuasa Roh Kudus, sehingga firman Tuhan yang disampaikan berkuasa dan Alkitabiah. Tuhan Yesus berkata:

"Tetapi Aku berkata kepadamu, setiap kata-kata yang diucapkan orang harus dipertanggungjawabkan pada hari penghakiman, karena menurut ucapanmu engkau akan dibenarkan, dan menurut ucapanmu pula engkau akan dihukum." 45

Dari perkataan Tuhan Yesus di atas, maka seorang pengkhotbah harus menjunjung tinggi Alkitab yang adalah firman Allah yang memilki otoritas tertinggi. Pengkhotbah ada akhirnya ia harus mempertanggungjawabkan khotbah dihadapan Tuhan. Oleh sebab itu seorang pengkhotbah ekspositori harus memiliki kriteria dimana pikiran dan perasaannya hanya di dalam Kristus. Sama seperti yang dikatakan oleh rasul Paulus, "hendaklah kamu dalam hidupmu bersama menaruh pikiran dan perasaan yang terdapat juga dalam Kristus Yesus." 46

Khotbah ekspositori berpusat pada kesaksian Alkitab tentang perbuatanperbuatan Allah dalam Tuhan Yesus Kristus. James Braga mengutip perkataan Dr. James M. Gray yang mengatakan "Khotbah ekspositori menuntut agar khotbah mencantumkan lebih banyak kebenaran Alkitab murni dan pandangan Alkitabiah." 47

Seorang pengkhotbah dalam menyampaikan khotbah harus menyampaikan dengan memperhatikan seluruh maksud Allah yang telah ada di dalam Alkitab. ${ }^{48}$ Dengan demikian nas yang akan dikhotbahkan, ditafsirkan dengan memperhatikan konteks kebenaran menurut Alkitab secara menyeluruh yakni dari kitab Kejadian sampai dengan Wahyu. Alkitab memang terdiri dari beberapa kitab dan ditulis oleh beberapa orang melalui pengilhaman Roh Allah, namun semuanya merupakan satu kesatuan yang berasal dari Allah.

\section{Suatu Hasil Hermeneutika Yang Baik}

Pada waktu para sarjana hermeneutika mendekati penafsiran Alkitab, mereka menjelaskan hermeneutika dibagi dalam dua bagian yaitu: prinsip umum dan prinsip khusus. Prisnsip umum adalah prinsip-prinsip secara umum yang perlu diperhatikan untuk menafsirkan Alkitab. Prinsip khusus adalah prinsip tafsiran khusus yaitu Alkitab dianggap sebagai suatu bagian dari karya sastra, maka prinsip khusus diperlukan yang berpusat pada metode pembentukan secara sastra.

Khotbah ekspositori dikatakan suatu hasil hermeneutika yang baik karena dalam menginterpretasi teks firman Tuhan, pengkhotbah sangat memperhatikan prinsipprinsip hermeneutika seperti analisa konteks historis, konteks kalimat, sintaksis dan gramatika dari Alkitab. ${ }^{49}$

Penafsiran merupakan unsur penting dalam khotbah. Penafsiran yang tepat dan benar memungkinkan pengkhotbah menyampaikan isi khotbah yang tepat dan benar. ${ }^{50}$ Dengan demikian penafsiran merupakan salah satu unsur yang penting dalam berkhotbah. Penafsiran yang mendalam sebuah teks dengan memperhatikan proses penafsiran seperti: analisis teks, analisis introduksi, analisis sejarah dan latar belakang,

\footnotetext{
${ }^{45}$ Matius 12:36-37

${ }^{46}$ Filipi 2:5

${ }^{47}$ James Braga, Cara Mempersiapkan...hlm. 71

${ }^{48}$ J. Gulleson, Bagaimana Berkhotbah Jenis Ekspositori, (Surabaya: YAKIN, 1984), hlm.13

${ }^{49}$ Walter C. Kaisar Jr, Toward An Exegetical Theology, (Grand Rapids, Michigan: Zondervan Publishing House, 1989), p.69-85.

${ }^{50}$ Hasan Susanto, Homiletik...hlm. 137.
} 
analisis sastra, konteks, arti kata dan tata bahasa, akan membawa suatu khotbah dalam pengungkapan akan kekayaan firman Allah.

Searah dengan hal ini Robinson memberikan beberapa tahap pengembangan pesan-pesan ekspositori. Ada 10 tahap pengembangan ekspositori yang baik, memilih nukilan Alkitab, mempelajari nats Alkitab, menemukan ide eksegetikal, menganalisis ide eksegetikal, merumuskan ide eksegetikal, menentukan tujuan khotbah, menentukan cara untuk mencapai tujuan ini, membuat kerangka khotbah, mengisi kerangka khotbah, menyiapkan pengantar dan kesimpulan. ${ }^{51}$

Pesan-pesan yang disampaikan dalam khotbah dapat diresponi dengan baik oleh pendengar, jikalau pengetahuan dan kehidupan pengkhotbah telah ditaklukkan di bawah kuasa Roh Kudus. Hasil dari karya Roh Kudus akan nampak pada saat Firman Allah dikomunikasikan kepada para komunikan dan akan merasakan bahwa Allah sedang berbicara dan membuka rahasia-rahasia yang belum diketahui oleh jemaat.

Pengkhotbah yang dipimpin oleh Roh Kudus akan mampu menafsirkan, menggali dan mengekspos keluar arti yang sebenarnya dari teks, dan menyajikannya kepada para pendengar melalui khotbah. Pada akhirnya pendengar memahami kebenarankebenaran Allah yang dapat memperbaharui sikap hidupnya.

Khotbah ekspositori yang telah memenuhi prinsip hermeneutika yang baik akan membawa pendengar kepada suatu doktrin yang benar dan Alkitabiah, baik tentang theologi, bibliologi, anropologi, soteriologi, ekklesiologi dan eskatologi. Tetapi penafsiran yang salah akan membawa pendengar dalam bahaya penyesatan.

\section{Disampaikan Dalam Kuasa Roh Kudus}

Alkitab diwahyukan kepada para penulis melalui perantaraan Roh Kudus. Oleh karena itu khotbah ekspositori disampaikan dengan kuat kuasa Roh Kudus. Hanya Roh Kuduslah yang dapat menerapkan firman Allah yang disampaikan pada hati pendengar.

Rasul Paulus megatakan bahwa orang-orang yang belum percaya, telah dibutakan oleh ilah jaman ini sehinga mereka tidak melihat cahaya Injil tentang kemuliaan Kristus. ${ }^{22} \mathrm{Hal}$ ini juga sedang melanda sebagian orang-orang percaya yang sudah mulai buta akan kebenaran firman Allah, hampir setiap gereja mengalami kemerosotan dan kemunduran dalam kerohanian. Oleh karena itu perlu pimpinan Roh Kudus untuk membuka setiap hati yang keras dan membukakan mata yang buta sehingga firman Allah boleh sampai pada mereka.

Khotbah akan berkuasa apabila pengkhotbah membina hubungan doa dan penyembahan kepada Allah. Hal ini dimulai dengan persiapan pribadi si pengkhotbah untuk mendapat berkat secara khusus bagi diri sendiri.

Warren W. Wiersbe mengatakan:

“Kebenaran tanpa kasih adalah kasar dan dapat melukai hati orang, tetapi kasih tanpa kebenaran adalah kasih yang dangkal, tidak sepenuh hati dan sentimental. Kasih dan kebenaran kedua-duanya diperlukan, karena Roh Kebenaran itu adalah juga Roh yang mengahasilkan kasih di dalam hati kita,"53

Kasih memberikan kepada pengkhotbah suatu keyakinan akan kuasa dan kekuatan Roh serta kerendahan dihadapan Tuhan sehingga hikmat tidak tergantung kepada manusia melainkan kepada Allah. Meskipun semua sudah beres dan telah disiapkan dengan seksama oleh pengkhotbah, tetapi kalau pengkhotbah tidak

\footnotetext{
${ }^{51}$ Robinson, Cara Berkhotbah Yang...hlm. 181.

${ }^{52}$ II Korintus 4:4

${ }^{53}$ Warren W. Wiersbe, Prioritas Seorang Pendeta, (Malang: Penerbit Gandum Mas, 1982), hlm.18.
} 
bersandar pada Roh Kudus dan Roh Kudus tidak bekerja melalui pengkhotbah semuanya sia-sia belaka. ${ }^{54}$ Searah dengan ini Rasul Paulus berkata:

"Baik perkataanku maupun pemberitaanku tidak kusampaikan dengan kata-kata hikmat yang kuyakini, tetapi kayakinan akan kekuatan Roh, supaya iman kamu jangan bergantung pada hikmat manusia, tetapi pada kekuatan Allah. Sebab Injil yang kami beritakan bukan disampaikan kepada kamu dengan kata-kata saja tetapi juga dengan kekuatan oleh Roh Kudus dan dengan suatu kepastian yang kokoh." 55

Berkhotbah tidak sama dengan pidato. Pidato membawakan ide-ide yang dirangkum sedemikian rupa untuk menjawab persoalan-persoalan yang muncul atau yang diangkat serta mencari jalan keluarnya. Jawaban-jawaban bisa saja berlandaskan hikmat dunia/manusia saja. Sedangkan khotbah hampir sama dengan pidato, tetapi seluruh jawaban atas persoalan yang diangkat, semuanya berdasarkan atau dalam terang firman Tuhan.

Seorang pengkhotbah tidak tergantung pada kemampuan retorikanya semata melainkan harus didukung oleh kerendahan hati dihadapan Tuhan Yesus Kristus yang adalah Firman itu sendiri. Roh Kudus berperan untuk menyadarkan komunikator dan komunikan pada otoritas Allah Bapa dan Anak. Akhirnya pemberitaan firman Allah melalui khotbah ekspositori sepadan dengan realitas dan otoritas Allah kepada pikiran dan hati manusia.

Seorang pengkhotbah akan mendapat hasil khotbah yang baik dengan kuat kuasa Roh Kudus apabila ia telah diperbaharui oleh Roh Kudus, memiliki kerendahan hati, menaati firman Tuhan dan bersedia menyampaikan firman Tuhan kepada orang lain. Seorang pengkhotbah yang sungguh berhasil adalah pengkhotbah yang menyiapkan khotbahnya dengan teliti dan seksama kemudian bersandar total kepada pekerjaan Roh Kudus. Khotbah yang sempurna tidak akan berhasil tanpa pengurapan dan pimpinan Roh Tuhan.

Pentingnya khotbah ekspositori harus disampaikan dengan kuat kuasa Roh Kudus, karena Roh Kuduslah yang dapat menginsyafkan setiap orang sehingga khotbah tanpa kuasa Roh adalah khotbah yang sia-sia.

\section{Memiliki Aplikasi Yang Tetap Relevan Tana Menyimpang Dari Kebenaran Firman Tuhan}

Penerapan atau aplikasi merupakan salah satu unsur yang paling penting dalma khotbah. Tuntutan-tuntutan firman Allah dipusatkan kepada individu agar ia dapat memberi tanggapan yang baik kepada pesan khotbah. ${ }^{56}$ Aplikasi sering dilukiskan dalam homelitika sebagai proses seorang pengkhotbah dalam mendorong pendengarpendengarnya untuk memberi tanggapan yang baik kepada kebenaran yang dinyatakan oleh Allah.

Seorang pengkhotbah perlu memahami jemaatnya supaya ia mengerti keluhan, pergumulan hati dan kebutuhan jemaatnya, sehingga firman Allah dapat diaplikasikan kepada para pendengar.

Khotbah ekpositori akan memiliki aplikasi yang relevan apabila pengkhotbah telah mengalami pengurapan Roh Kudus dan telah melakukan prinsip-prinsip hermeneutika yang baik. Seorang yang mengkomunikasikan khotbah ekspositori harus

\footnotetext{
${ }^{54}$ J. Gulleson, Bagaimana Berkhotbah...hlm. 78

${ }^{55}$ I Korintus 2:45; I Tesalonika 1:5

${ }^{56}$ James Braga, Cara Mempersiapkan...hlm 183
} 
punya relasi pribadi dengan Allah dan firman Allah menjadi bagian dalam hidupnya. Pengkhotbah yang baik harus dapat mempertanggungjawabkan khotbahnya yang akan nampak dalam kehidupan praktis tiap-tiap hari. Wiersbe mengutip perkataan Spurgeon yang berbunyi demikian "Jangan melemparkan butir-butir gandum kepada jemaat-jemaatnya, tetapi gandum itu harus digiling kemudian diolah menjadi roti sesudah itu irislah roti itu dan sebaiknya diberi sedikit madu untuk selanjutnya diberikan kepada jemaat." 57

Pernyataan di atas memberikan suatu petunjuk bahwa tanggung jawab yang benar dari seorang pengkhotbah adalah terlihat dari motivasi dan pengorbanannya dalam menyiapkan dan menyampaikan suatu khotbah. Aplikasi yang benar dan relevan akan dicapai kalau penafsiran Alkitab tidak menyimpang dari kebenaran Firman Tuhan.

Kegagalan banyak pengkhotbah sekarang ini disebabkan adanya pemaksaan kebenaran firman Allah untuk mendukung ide atau gagasan yang telah disusun sebelumnya dan kurang bersandar serta mendengar suara Allah dalam memberikan jawaban atas kebutuhan umat-Nya. Hal ini menjadi keharusan bagi seorang pengkhotbah untuk mengerti sedapat mungkin makna yang terkandung dalam nas atau ayat-ayat Alkitab. Akhirnya aplikasi yang disampaikan sesuai dengan kebutuhan jemaat dan tidak menyimpang dari kebenaran keseluruhan Alkitab yang adalah firman Allah.

\section{Keunggulan Khotbah Ekspositori}

Dalam berkhotbah jenis ekspositori ada beberapa keunggulan yang terdapat di dalamnya yang membawa pengkhotbah untuk lebih menguasai Alkitab, yakni: firman Tuhan diajarkan, menambah wawasan yang luas terhadap firman Allah, subjektifitas pengkhotbah dapat diatasi, kesulitan dalam memilih teks dapat dipecahkan dan pengkhotbah diyakinkan. ${ }^{58}$

\section{Mengajarkan Firman Tuhan}

Dalam bagian awal telah dijelaskan tentang khotbah ekspositori dimana khotbah ini berdasarkan suatu konsep Alkitabiah yang diperoleh melalui studi historis, gramatikal, dan kesusastraan Alkitab sesuai dengan konteksnya, yang pertama-tama dialami oleh pengkhotbah secara pribadi melalui pimpinan Roh Kudus dan baru diaplikasikan kepada jemaat.

Jika pengkhotbah memakai khotbah ekspositori, ia harus bergumul dengan nas Alkitab. Oleh karena itu dia harus belajar firman Allah. perkataan ini dapat dipakai baik untuk pengkhotbah sendiri maupun untuk para pendengar yang mendengar khotbah. ${ }^{59}$ Melalui khotbah ekspositori pendengar belajar firman Allah, karena nas Alkitab menjadi pusat khotbah. Jadi melalui khotbah ekspositori pengkhotbah dan pendengar bersama-sama bertumbuh secara Alkitab. Khotbah ekspositori menekankan inti utama dari Alkitab dan memberikan dorongan kepada para pendengar untuk memperhatikan teks Alkitab.

Khotbah ekspositori lebih banyak menjelaskan ulasan secara luas ayat-ayat Alkitab, yang disajikan secara hidup dan relevan untuk masa kini. Selain itu khotbah ekspositori lebih banyak menggunakan bahan-bahan dari Alkitab dibandingkan dengan

\footnotetext{
${ }^{57}$ Warren W. Wiersbe, Prioritas Seorang Pendeta...hlm. 14.

${ }^{58}$ Poin-poin ini di ambil dari buku D. W. Lee, yang berjudul "Khotbah Ekspositori yang Menmbangunkan Pendengar".,

${ }^{59}$ D. W. Lee, Khotbah Ekspositori yang Membangun...hlm. 120.
} hlm.120-122. 
khotbah jenis yang lain. ${ }^{60}$ Dengan demikian dapat lebih banyak menolong pendengar karena mengulas berbagai ragam masalah dan situasi kehidupan jemaat.

\section{Memiliki Wawasan Yang Luas Terhadap Firman Allah}

Seorang pengkhotbah ekspositori jika berkhotbah ekspositori secara berseri, maka bagian yang biasanya tidak dikhotbahkan juga harus akan dikhotbahkan. ${ }^{61}$ Oleh karena itu pengkhotbah harus mempelajari teks Alkitab yang biasanya tidak dipelajari. Proses ini akan dapat memperluaskan khotbah, karena teks Alkitab yang baru dipelajari serta perhatian pengkhotbah menjadi luas.

Untuk berkhotbah jenis ekspositori seorang pengkhotbah mau tidak mau harus mempunyai minat dan semangat belajar terus-menerus dengan membaca buku-buku dan memperhatikan bagian-bagian atau tema-tema baru, sehingga dapat memperluas konsep pengkhotbah. ${ }^{62}$

Dengan menggunakan khotbah jenis ekspositori, pengkhotbah di motivasi untuk belajar lebih banyak tentang study literatur. Hal ini membawa pengkhotbah dapat memiliki wawasan yang luas dan tentang firman Tuhan.

\section{Subjektifitas Pengkhotbah Di Atas}

Khotbah ekspositori dapat mengatasi dan mencegah pengkhotbah jatuh ke dalam pikiran subjektif diri sendiri, oleh karena cara khotbah ekspositori yang lebih menekankan hubungan pengkhotbah dengan Allah melalui urapan Roh dan perenungan firman Allah. ${ }^{63}$ Sehingga yang menjadi inti utama dari khotbah ekspositori adalah bagaimana pengkhotbah menemukan berkat rohani dari teks atau nas Alkitab yang akan dikhotbahkan.

Pengkhotbah ekspositori sebelum berkhotbah harus menyiapkan diri dengan baik yang dimulai dengan doa untuk memohon pimpinan Roh Kudus. Di dalam merenungkan dan memberitakan firman Tuhan selalu terfokus pada kebenaran Alkitab. ${ }^{64}$

Oleh kerena itu pengkhotbah ekspositori akan selalu jauh dari subjektifitas diri sendiri, karena yang menjadi patokan terpenting dalam khotbah ekspositori adalah bagaimana hubungan pribadi dengan Allah yang dilakukan lewat doa serta bagaimana menemukan kebenaran sejati di dalam Alkitab yang adalah firman Allah.

\section{Kesulitan Memilih Teks Dapat Dipecahkan}

Seorang pengkhotbah biasanya mengalami kesulitan di dalam menentukan topik yang akan dikhotbahkan. Apabila seseorang berkhotbah jenis ekspositori, waktu untuk memilih teks dapat dipakai untuk menyiapkan khotbah, sehingga kesulitan dalam memilih teks dapat dipecahkan. ${ }^{65}$

Dalam berkhotbah jenis ekspositori teks-teks firman Tuhan yang akan dikhotbahkan tidak akan pernah habis, oleh karena pengkhobah hidup di dalam firman Tuhan yakni membaca dan merenungkan firman Tuhan. Sumber khotbah ekspositori akan senantiasa ada, karena pengkhotbah tidak hanya dapat menyusun khotbah

\footnotetext{
${ }^{60}$ Charles W. Koller, Khotbah Ekspositori Tanpa Cacatan, (Bandung: Yayasan Kalam Hidup tt), hlm.28-29.

${ }^{61}$ D. W. Lee, Khotbah Ekspositori yang Membangun...hlm. 120.

${ }^{62}$ Yosua SungOh Park, Wawancara Pribadi, Tanjung Enim 26 Agustus 2004.

${ }^{63}$ D. W. Lee, Khotbah Ekspositori yang Membangun...hlm. 121-122.

${ }^{64}$ Yosua SungOh Park, Wawancara Pribadi, Tanjung Enim 26 Agustus 2004.

${ }^{65}$ D W. Lee, Khotbah Ekspositori yang Membangun....hlm.122.
} 
bedasarkan beberapa ayat atau perikop saja tetapi juga dapat berdasarkan satu pasal atau seluruh kitab dalam Alkitab.

Dengan demikian sumber dan bahan khotbah ekspositori tidak pernah habis, karena pengkhotbah memiliki daya kreatifitas dalam mengembangkannya di samping memiliki wawasan literatur yang Alkitabiah. ${ }^{66}$

\section{Pengkhotbah Diyakinkan}

Berkhotbah ekspositori dapat mencegah pemikiran pribadi pengkhotbah. Jadi khotbah itu menjadi kerygma Allah yang benar dan pengkhotbah percaya bahwa inilah pesan dari Allah sendiri, bukan hanya pesan dari si pengkhotbah. ${ }^{67} \mathrm{Hal}$ ini memberi keyakinan di mimbar kepada si pengkhotbah dan menjadi hal pokok yang penting untuk memiliki rasa bangga dalam menyampaikan firman Allah.

Pengkhotbah jenis ekspositori memiliki kepercayaan diri dalam berkhotbah, karena ia terlebih dahulu telah memiliki persiapan yang matang dengan pengurapan dari Roh Kudus. Jenis khotbah ekspositori mengharuskan pengkhotbah untuk melakukan langkah-langkah berkhotbah dan penafsitan sehingga kebenaran yang di dapat adalah kebenaran Allah melalui hasil perenungan pengkhotbah secara pribadi. Melalui khotbah ekspositori pengkhotbah dapat berdiri di mimbar degan penuh keyakinan sebab yang disampaikan adalah kebenaran dari Allah.

\section{Unsur-Unsur Khotbah Ekspositori}

Dalam berkhotbah jenis ekspositori ada beberapa unsur yang merupakan hal penting dalam berkhotbah, yaitu: Teks Firman Tuhan, Pengkhotbah, Jemaat dan Peranan Roh Kudus. Kalau unsur-unsur ini tidak terpenuhi maka sudah barang tentu tidak dapat menghasilkan khotbah ekspositori yang baik.

\section{Teks Firman Tuhan}

Seorang pengkhotbah memiliki tugas utama yakni memberitakan dan menyampaikan firman Tuhan. Tuhan Yesus berkata "pergilah keseluruh dunia, beritakanlah Injil kepada segala makhluk". ${ }^{68}$ Tuhan Yesus, memberitakan tugas utama adalah memberitakan dan menyampaikan Injil kepada semua orang. Dengan demikian tugas gereja yang paling utama adalah menyampaikan firman Tuhan.

Menyampaikan khotbah ekspositori merupakan suatu aktivitas yang harus diutamakan dari pada yang lain. Ketika firman Tuhan disampaikan dengan setia kepada jemaat, segala berkat akan dinyatakan bagi mereka. Yosua Park mengutip pernyataan Oswald Chambels yang mengatakan bahwa: "para pengkhotbah, tatkala saudara terharu oleh firman Tuhan yang ingin disampaikan, janganlah tawarkan firman-Nya jika firman itu datang dari Tuhan, majulah berjuanglah secara langsung bagi Tuhan, tidak boleh kompromi dengan unsur apapun. ${ }^{69}$ Oleh karena itu inti yang pentig di dalam berkhotbah ekspositori adalah firman Tuhan disampaikan kepada jemaat. Firman Tuhan yang disampaikan harus berpusatkan kepada Tuhan Yesus, menyatakan dengan jelas bahwa manusia telah jatuh ke dalam dosa, serta pengampunan melalui darah Kristus.

\footnotetext{
${ }^{66}$ Charles W. Koller, Khotbah Ekspositori Tanpa...hlm.30-31.

${ }^{67}$ D W. Lee, Khotbah Ekspositori yang Membangun....hlm.122.

${ }^{68}$ Markus 16:15

${ }^{69}$ Yosua SungOh Park, Theologi Pengertian Khotbah Ekspositori, (Tanjung Enim: Diktat,2004),hlm.4
} 


\section{Pengkhotbah}

Seorang pengkhotbah mempunyai kewajiban berat adalah menyampaikan firman Allah. Rasul Paulus mengatakan jadi kami ini adalah utusan-utusan Kristus, seakan-akan Allah menasehati kamu dengan perantaraan kami; dalam nama Kristus kami meminta kepadamu; berilah dirimu didamaikan dengan Allah. ${ }^{70}$

Pengkhotbah merupakan utusan dan duta Allah dalam menyampaikan firman Tuhan. Oleh karena itu seorang pengkhotbah harus mempersiapkan diri dengan baik dalam menyampaikan firman Tuhan. Roh Kuduslah yang harus berdiam di dalam diri pengkhotbah. Yang terpenting sebagai pengkhotbah adalah mempersiapkan diri sebagai pengkhotbah dengan baik seperti mempersiapkan khotbahnya. ${ }^{71} \mathrm{Hal}$-hal yang perlu diperhatikan dalam diri pengkhotbah adalah:

\section{Kepribadian}

Seorang pengkhotbah adalah seorang yang telah mengalami hidup baru, telah menjadi orang Kristen yang sejati dan menerima Tuhan Yesus sebagai juru selamatnya secara pribadi. Sehingga seorang pengkhotbah merupakan pribadi yang menjadi teladan dan panutan bagi orang lain. Sebab orang yang belum dilahirkan kembali tidak mungkin dapat mengerti firman Allah dan dapat melihat kerajaan Allah.

Pengkhotbah ekspositori harus sungguh-sungguh mempunyai kepribadian yang baik dengan yang memiliki hati kasih dan penjaga kesucian hidup, mengetahui kebenaran Allah, menerima dan mengikuti pimpinan dan Roh Kudus, baru ia dapat berkhotbah dan memberitakan Injil. ${ }^{72}$

Tugas pengkhotbah adalah menguraikan kebenaran Allah yang telah ada di dalam Alkitab dan mengaplikasikannya. Sehingga pengkhotbah merupakan seorang pribadi pejuang untuk menyelamatkan jiwa-jiwa yang telah jauh dari Tuhan, dengan demikian ia harus memberi waktu untuk membaca Alkitab, untuk study dan membaca buku-buku, sama halnya dengan berperang. ${ }^{73}$

\section{Doa}

Khotbah akan berkuasa bila pengkhotbah hidup di dalam doa. Mulai dari persiapan khotbah sampai pada penyampaian khotbah harus dimulai dengan doa untuk meminta pimpinan dari Tuhan melalui Roh Kudus.

Doa adalah berhubungan atau berbicara dengan Allah. Doa merupakan pernyataan ketergantungan manusia kepada Allah untuk segala sesuatu. ${ }^{74}$ Oleh sebab itu doa merupakan unsur yang terpenting yang tidak dapat dipisahkan dari pribadi pengkhotbah. Searah dengan hal ini J.D. Douglas mengatakan:

Dalam Alkitab doa adalah kebaktian mencakup segala sikap roh manusia dalam pendekatannya kepada Allah. Orang kristen berbakti kepada Allah jika ia memuja, mengakui, memuji dan mengajukan permohonan kepada-Nya dalam doa. Doa sebagai perbuatan tertinggi yang dapat dilakukan oleh Roh manusia, dapat juga dipandang sebagai persekutuan dengan Allah, selama penekanannya diberikan kepada prakarsa ilahi. 75

\footnotetext{
${ }^{70}$ II Korintus 5:20.

${ }^{71}$ Yosua sugOh Park, Theologi Pengertian Khotbah...hlm7.

${ }^{72}$ Hasan Susanto, Homiletik...hlm.76.

${ }^{73}$ Yosua SungOh Park, Theologi Pengertian Khotbah...hlm.7.

${ }^{74}$ J. Wesley Brill, Doa-doa dalam PL, (Bandung: Kalam Hidup, tt) hlm.9.

${ }^{75}$ J.D. Douglas, Ensiklopedi Alkitab Masa Kini, (Jakarta: Yayasan Komunikasi Bina Kasih/OMF,1999), hlm 249.
} 
Dengan demikian kehidupan doa merupakan suatu kebutuhan manusia yang mutlak harus dimiliki oleh setiap orang Kristen dan terlebih lagi oleh setiap pengkhotbah. Sebab manusia pada dasarnya lemah dalam segala hal. Itulah sebabnya manusia harus penuh menyerahkan diri kepada Allah yang mempunyai kuasa. Pelayanan tanpa dimulai melalui doa yang sungguh-sungguh, sama sekali tidak mendatangkan kuasa Allah. Segala khotbah harus dikuduskan dengan doa, baik di dalam persiapan, penyajian maupun pemeliharaannya. ${ }^{76}$ Dengan demikian semua kegiatan rohani secara khotbah dapat berhasil dan bermanfaat bagi setiap orang apabila didasari di dalam doa.

\section{Pengakuan}

Pemahaman theologia yang baik dan benar bagi seorang pengkhotbah sangat penting mengingat apa yang disampaikannya akan dapat mempengaruhi kehidupan orang lain. Untuk itu perlu upaya yang sungguh-sungguh bagi seorang pengkhotbah tentang pengetahuan dan pemahaman akan firman Tuhan. Sebab khotbah ekspositori suatu khotbah yang melekat pada karakter pegkhotbah, sehingga ia harus terus berusaha untuk terus menemukan khotbah melalui jamahan Tuhan yang lebih dulu memberkatinya. ${ }^{77}$

Seorang penkhotbah yang memberitakan firman Allah adalah seorang yang mencintai Alkitab dan karena itu ia menyelidiki dan merenungkannya. Hal ini penting sebab orang yang berani berkhotbah harus bertanggungjawab kepada Tuhan dan pendengarnya bahwa ia sungguh memahami firman Tuhan yang hendak disampaikannya. Sehingga pendengar tidak dibawa kepada pemahaman yang keliru yang tidak sesuai dengan kebenaran firman Tuhan. ${ }^{78}$

Dengan demikian seorang pengkhotbah ekspositori adalah seorang yang harus fasih dalam pengetahuan Alkitab dan pemahaman theologi yang baik dan benar, sehinnga jemaat yang mendengarkan mendapat pengetahuan baru dalam hidupnya.

\section{Pendengaran}

Dalam suatu khotbah unsur jemaat atau pendengar merupakan unsur kedua yang harus diperhatikan oleh seorang pengkhotbah dalam menyampaikan firman Tuhan. Mengerti kondisi dan situasi jemaat merupakan salah satu cara untuk dapat mencapai tujuan khotbah.

\section{Pendidikan}

Seorang pengkhotbah ekspositori harus memahami latar belakang pendidikan pendengar atau jemaat. Hal ini penting karena khotbah akan sampai apabila pengkhotbah menyentuh kebutuhan dan keperluan jemaat. Dengan mengerti latar belakang pendidikan pendengar, mempermudah pengkhotbah dalam menyampaikan dan mengaplikasikan khotbah.

Pengkhotbah akan dapat menyampaikan khotbah dengan bahasa yang sesuai dengan tingkat pengetahuan dan pendidikan pendengar. Khotbah yang disampaikan harus dengan bahasa sederhana yang mudah dimengerti oleh jemaat, sehingga jemaat

\footnotetext{
${ }^{76}$ Denis J.V. Lane, Britakan Firman, (Jakarta: BPK Gunung Mulai,1981), hlm.15-16

${ }^{77}$ Yosua SungOh Park, Theologi Pengertian Khotbah...hlm.9.

${ }^{78}$ Hendra Rey, Homiletika...hlm.13.
} 
dapat diberkati melalui Firman Tuhan, dengan demikian latar belakang pendidikan pendengar harus menjadi perhatian pengkhotbah sebelum ia khotbah.

\section{Ekonomi}

Kondisi ekonnomi jemaat merupakan salah satu hal yang penting yang perlu diperhatikan oleh pengkhotbah sebelum ia berkhotbah. Tidak mungkin suatu khotbah akan sampai dan menyentuh kehidupan pendengar jika pengkhobah berkhotba tentang keselamatan tetapi sedang dialami oleh pendengar kekurangan kebutuhan rumah tangga. Oleh karena itu pengkhotbah harus punya pengetahuan yang memadai sehingga berusaha sebaik mungkin untuk mendapat informasi tentang situasi jemaat yang akan dikhotbahkan.

\section{Rohani}

Sebelum penyampaian firman Tuhan pengkhotbah harus memperhatikan apakah pendengar sudah siap untuk menerima/mendengar sesuatu atau belum. Pengkhotbah harus memahami keadaan rohani jemaat yang akan mendengar firman Tuhan, apakah pendengar telah lahir baru atau belum, bahkan tingkat kerohanian pendengar kalau bisa harus dimengerti oleh seorang pengkhotbah. Sehingga mempermudah bagi pengkhotbah untuk menyampaikan Firman Tuhan kepada pendengar. Dengan demikian pengkhotbah menyampaikan firman Tuhan yang dapat menyentuh hati atau perasaan jemaat.

\section{Pertolongan Roh Kudus}

Khotbah ekspositori akan berhasil dengan baik apabila ada pengurapan dari Roh Kudus. Pengkhotbah harus selalu berusaha dan berdoa untuk dipenuhi Roh Kudus. Kepenuhan Roh Kudus dan doa memiliki hubungan yang erat. Pengkhotbah tidak beleh mengandalkan kemampuannya dan keahliannya bahkan timbul kesombongan dalam berkhotbah, tetapi harus sungguh-sungguh mengandalkan Tuhan secara total. Pengkhotbah juga merendahkan diri serta menyerahkan diri sebagai orang yang disalibkan bersama Tuhan. Sehingga keangkuhan, kesombongan, ketinggian hati dapat dipatahkan dibawah kaki salib Tuhan Yesus Kristus. Searah dengan hal ini E. M. Baunz mengatakan:

"Urapan Roh Kudus adalah skill keterampilan khotbah. Jika seorang pengkhotbah belum pernah diurapi Roh Kudus, berarti dia belum mempunyai skiil khotbah. Andai kata seorang pengkhotbah hilan urapan Roh Kudus artinyadia juga hilang skill khotbahnya. Sekalipun ia mempunyai skill-skill yang lain misalnya mampu dibidang sistematika, memiliki kekuatan mental, fasik dalam berbicara, mampu menarik perhatian dan sebagainya. Walaupun ia memiliki demikian kalau tanpa urapan Roh Kudus semua itu tidak berarti. Maka kepenuhan urapan Roh kudus mampu membuat khotbah yang menarik, dapar mengajar Firman Tuhan, dapat menyadarkan dosa dan berpengaruh bagi orang lain serta memberikan keselamatan bagi orang lain. 79

Dengan demikian Roh Kudus mempunyai peranan penting dalam menghasilkan sebuah khotah yang baik, menarik dan Alkitabiah. Roh Kudus hadir dalam diri pengkhobah yang telah lahir baru dan yang hidup bergaul dengan Allah. Sehingga dapat mengerti firman Tuhan yang diilhamkan, serta hidup dengan hati yang berkobar-

\footnotetext{
${ }^{79}$ Yosua SungoH Park, Theologia pengertian khotbah...hlm.14
} 
kobar dan dapat menyadarkan dosa pendengar serta mampu membukakan isi hati orang lain.

\section{Simpulan}

Khotbah jenis ekspositori merupakan pilihan yang sangat tepat untuk menjawab tantangan kebutuhan pemberitaan Firman Tuhan masa kini. Struktur khotbah ekspositori yang sistematis serta diuraikan dalam satu rangkaian pokok-pokok besar dan kecil, serta tema yang saling berhubungan satu dengan yang lainnya sangat memudahkan pendengan untuk mengingat bagian dari khotbah, baik temanya maupun isinya. Di sisi lain ekspositori juga menolong si-pengkhotbah untuk konsisten menguraikan bagian firman Tuhan sesuai dengan nats yang sudah dibacakan.

Pada umumnya gereja/jemaat masa kini menyenangi pemberitaan firman yang tegas jelas padat serta gampang dimengerti oleh para pendengarnya. Ini semua ada dalam khotbah ekspositori, karena seorang pengkhotbah selalu dipandu serta dibatasi oleh bagian-bagian yang diangkat dari teks atau nats yang telah dibaca sebagai landasan pemberitaan firman Tuhan, dan tiap tema hanya terdiri dari tiga atau paling banyak empat bagian saja, tidak boleh lebih dari itu.

Melihat perkembangan dunia yang semakin canggih, khususnya dibidang ilmu pengetahuan, maka khotbah ekspositori merupakan bagian dari perkembangan yang diciptakan oleh para ahli homiletika untuk menjadi solusi dalam pengajaran dan pemberitaan Firman Tuhan yang Alkitabiah, sistematis, serta mudah dipahamai oleh pendengarnya. 


\section{Daftar Pustaka}

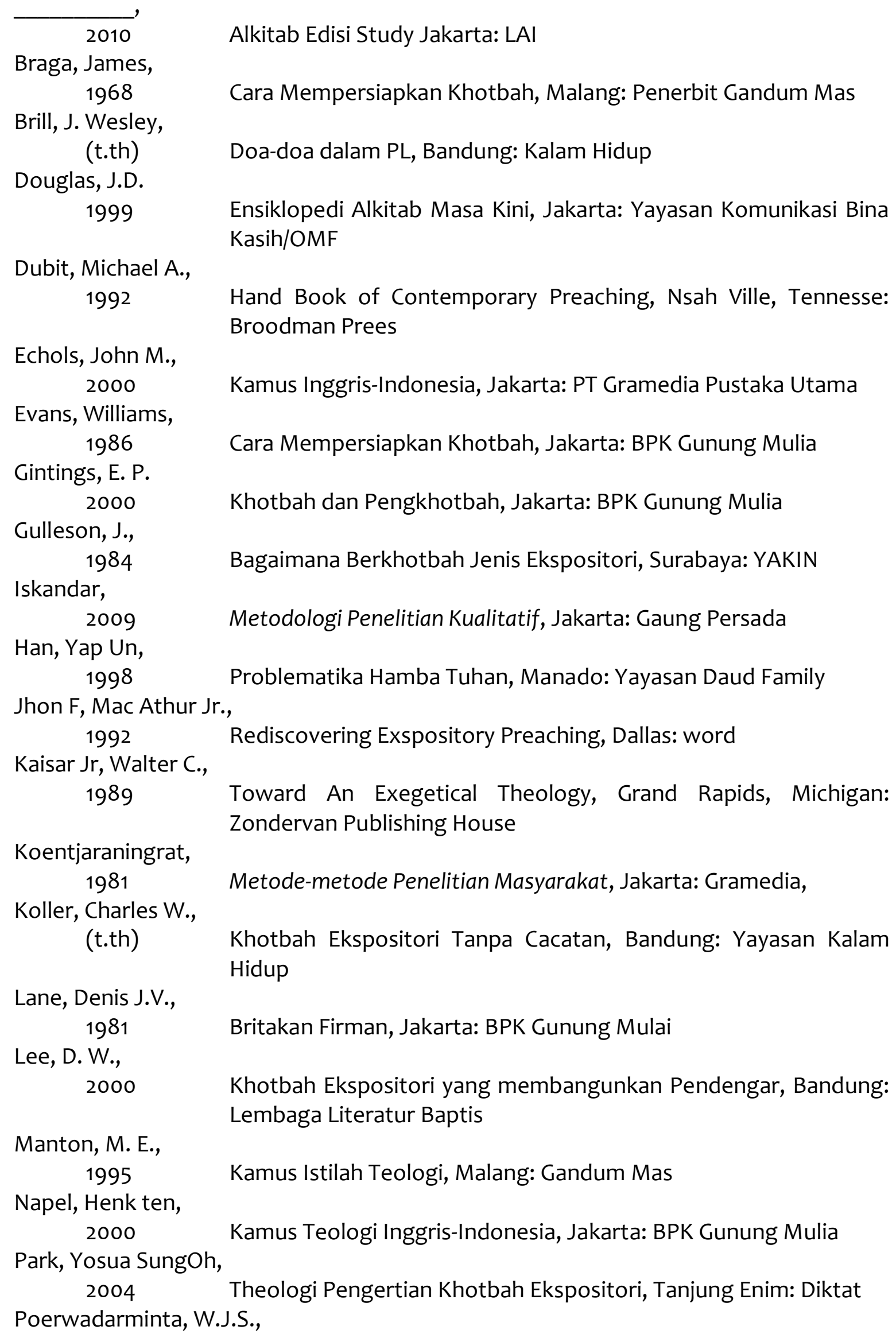


1991 Kamus Umum Bahasa Indonesia, Jakarta: Balai Pustaka

Pouw, H. P.,

(t.th) Homeletik, Bandung: Kalam Hidup

Simpson, D. P.,

1971

Compact Latin Dictionary, New York: Dell Publishing co-inc

Sumanto,

(t.th)

Metodologi Penenlitian Sosial dan Pendidikan, Yogyakarta: Andi Offset

Susanto, Hasan, 2004

Homelitik (Prinsip dan Metode Berkhotbah), Jakarta: BPK Gunung Mulia

Susanto, Hasan,

1995

Hermeneutik, (Prinsip dan Metode Penafsiran Alkitab), Malang: SAAT

Susanto, Hasan, 1995

Hermeneutik, Malang: Seminari Alkitab Asia Tenggara

Rey, Hendra,

(t.th)

Homelitika "Perlengkapan"

Robinson, Haddon W.,

2002 Cara Berkhotbah Yang Baik, Yoyakarta: Yayasan Andi

Vines, Jerry,

2002 Homelitik (Kuasa dalam berkhotbah), Malang: Gandum Mas

Vine, W. E.,

1985 Vine's Expository Dictionary of Biblical Word, Nashiville: Thomas Nelson Publisher

Wiersbe, Warren W.,

1982 Prioritas Seorang Pendeta, Malang: Penerbit Gandum Mas 